\title{
Corrigendum: Contribution of classical end-joining to PTEN inactivation in p53-mediated glioblastoma formation and drug-resistant survival
}

\author{
Youn-Jung Kang, Barbara Balter, Eva Csizmadia, Brian Haas, Himanshu Sharma, Roderick Bronson \\ $\&$ Catherine T. Yan
}

Nature Communications 8:14013 doi: 10.1038/ncomms14013 (2017); Published 17 Jan 2017; Updated 14 Aug 2017

'In the References section of this Article, the citation listed as reference 17 is incorrect, and should have referred to the following paper:

Forbes, S. A. et al. COSMIC: exploring the world's knowledge of somatic mutations in human cancer. Nucleic Acids Res. 43(Database issue): D805-D811 (2015).'

Open Access This article is licensed under a Creative Commons Attribution 4.0 International License, which permits use, sharing, adaptation, distribution and reproduction in any medium or format, as long as you give appropriate credit to the original author(s) and the source, provide a link to the Creative Commons license, and indicate if changes were made. The images or other third party material in this article are included in the article's Creative Commons license, unless indicated otherwise in a credit line to the material. If material is not included in the article's Creative Commons license and your intended use is not permitted by statutory regulation or exceeds the permitted use, you will need to obtain permission directly from the copyright holder. To view a copy of this license, visit http://creativecommons.org/licenses/by/4.0/
} 